\title{
Erratum to: Inequity in waiting for cataract surgery - an analysis of data from the Swedish National Cataract Register
}

\author{
Goldina Smirthwaite ${ }^{1 *}$, Mats Lundström², Barbro Wijma ${ }^{3}$, Nina Lykke ${ }^{4}$ and Katarina Swahnberg ${ }^{1}$
}

Unfortunately, after publication of this article [1], it was noticed that Figure 3 (Fig. 1 here) contained an error. The axis labels for the $\mathrm{x}$ axis allowed overlapping of the groups of data. The corrected figure can be seen below and the original article has been updated to reflect this change.

\section{Author details \\ ${ }^{1}$ Department of Health and Caring Sciences, Faculty of Health and Life Sciences, Linnaeus University, Kalmar 391 82, Sweden. ${ }^{2}$ Department of Clinical Sciences, Ophthalmology, Faculty of Medicine, Lund University, Lund, Sweden. ${ }^{3}$ Department of Clinical and Experimental Medicine, Faculty of Health Sciences, Linköping University, Linköping 581 83, Sweden. \\ ${ }^{4}$ Department of Gender Studies, Faculty of Arts \& Sciences, Linköping University, Linköping 581 83, Sweden.}

Received: 5 April 2016 Accepted: 6 April 2016

Published online: 11 April 2016

\section{References}

1. Smirthwaite G, Lundström M, Wijma B, Lykke N, Swahnberg K. Inequity in waiting for cataract surgery - an analysis of data from the Swedish National Cataract Register. Int J Equity Health. 2016;15:10. doi:10.1186/s12939-0160302-3.

\footnotetext{
* Correspondence: goldina.smirthwaite@Inu.se

Submit your next manuscript to BioMed Central and we will help you at every step:

- We accept pre-submission inquiries

- Our selector tool helps you to find the most relevant journal

- We provide round the clock customer support

- Convenient online submission

- Thorough peer review

- Inclusion in PubMed and all major indexing services

- Maximum visibility for your research

Submit your manuscript at www.biomedcentral.com/submit

\section{Biomed Central}




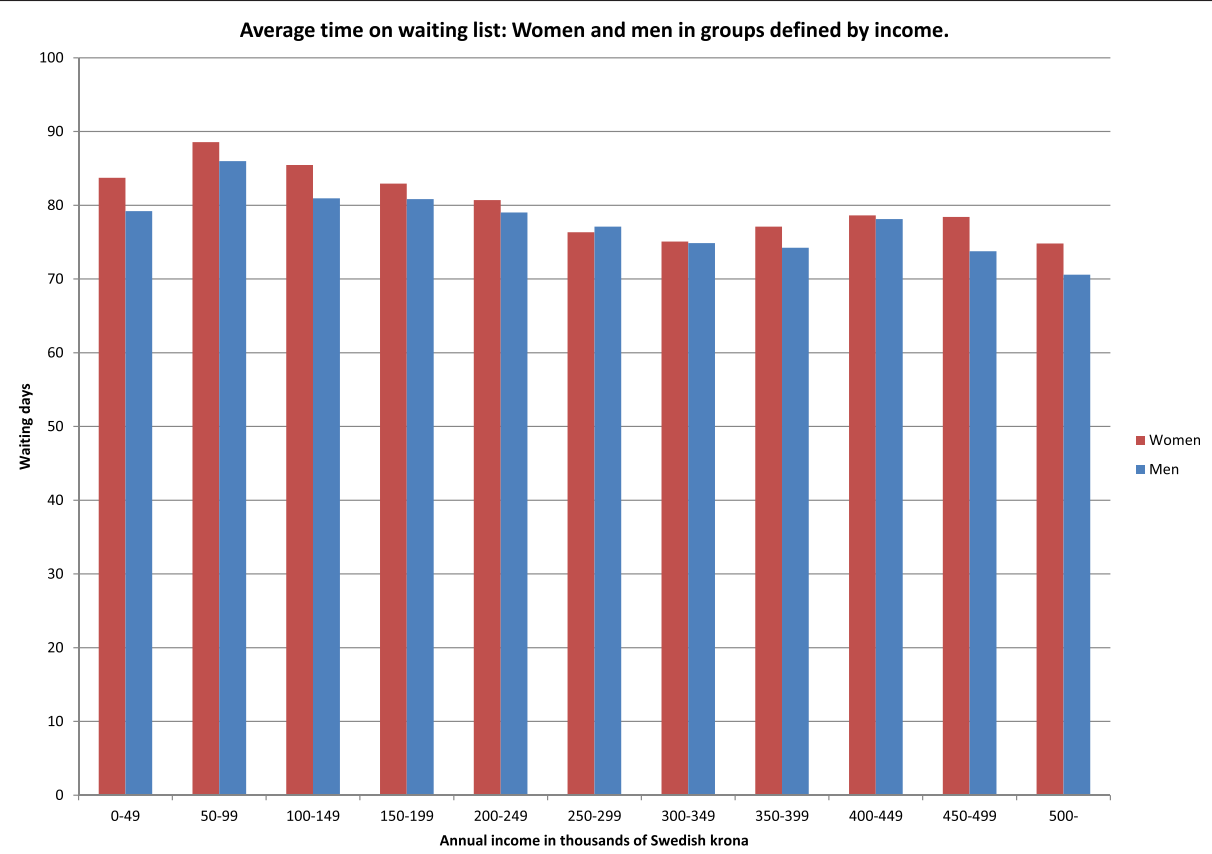

Fig. 1 Average time on waiting list Women and men in groups defined by income 